\title{
PERBEDAAN PRESTASI BELAJAR SISWA YANG MENGALAMI ADIKSI GAME ONLINE DENGAN SISWA YANG TIDAK MENGALAMI ADIKSI GAME ONLINE
}

Oleh:

\author{
Muhamad Mukmin ${ }^{1)}$, Wa Ode Suarni ${ }^{2)}$, Sudarmi Suud B ${ }^{3)}$ \\ 1) 2) 3) Jurusan Bimbingan dan Konseling \\ Fakultas Keguruan dan Ilmu Pendidikan, Universitas Halu Oleo \\ Email: muhammadmukmin014@gmail.com
}

\begin{abstract}
ABSTRAK
Penelitian ini bertujuan untuk mengetahui apakah terdapat perbedaan prestasi belajar siswa yang mengalami adiksi game online dengan siswa yang tidak mengalami adiksi game online di SMKN 2 Kendari. Jenis penelitian ini adalah penelitian komparatif.Subjek dalam penelitian ini 66 orang siswa. Hasil uji hipotesis dengan menggunakan uji independent sample t-test dengan taraf signifikan $a=0,05$ diperoleh sig. 2 tailed 0,00. Sig. 2 tailed $<a(0,00<0,05)$. Maka dapat disimpulkan terdapat perbedaan yang signifikan prestasi belajar siswa yang mengalami adiksi game online dengan siswa yang tidak mengalami adiksi game online di SMKN 2 Kendari.
\end{abstract}

Kata Kunci: Adiksi Game Online, Prestasi Belajar

\section{LEARNING ACHIEVEMENT DIFFERENCE BETWEEN ONLINE GAME ADDICTED AND ONLINE GAME UNADDICTED STUDENTS}

\begin{abstract}
The aim of this research is to find out wether there is a difference in learning achievement betwen online game addicted and unaddicted students. The subjects of this comparative study are 66 students. Based on Statistical analysis using t-test for independent sample the result shows that the difference is significant $(a 0,00<0,05)$. Therefore, it can be concluded that there is a learning achievement difference between online game addicted and online game unaddicted students of SMKN 2 Kendari.
\end{abstract}

Keywords: Online Game Addiction, Learning Achievement. 


\section{Pendahuluan}

Pendidikan merupakan hubungan antar pribadi pendidik dan anak didik. Hubungan ini jika meningkat ke taraf hubungan pendidikan, maka menjadi hubungan antara pribadi pendidik dan pribadi anak didik yang pada akhirnya melahirkan tanggung jawab pendidikan dan kewibawaan pendidikan. Di zaman yang semakin berkembang ini, pendidikan sangat memiliki pengaruh yang sangat besar dalam kehidupan kita semua, dengan pendidikan dapat mengarahkan dan meningkatkan cara berfikir manusia atau seseorang, menumbuhkan kreatifitas manusia untuk menciptakan hal-hal yang bermanfaat yang dapat membantu kegiatan manusia sendiri.

Pendidikan mengembangkan berbagai potensi yang ada dan yang dimiliki setiap individu dengan setinggi-tingginya baik itu dalam aspek fisik, intelektual, emosional, sosial dan spiritual, sesuai dengan tahap perkembangan serta karakteristik lingkungan fisik dan lingkungan sosial budaya di mana individu tersebut hidup. Pendidikan di Indonesia kini telah menunjukkan berbagai banyak perubahan dengan harapan bahwa sahnya kesadaran akan pentingnya pendidikan semakin besar, sehingga membangun semangat bagi setiap masyarakat Indonesia untuk memeroleh pendidikan yang lebih baik.

Pembelajaran adalah proses interaksi antara siswa dengan pendidik, sumber belajar pada suatu lingkungan belajar. Pembelajaran merupakan bantuan yang diberikan pendidik agar dapat terjadi proses perolehan ilmu dan pengetahuan, penguasaan kemahiran dan tabiat serta pembentukan sikap dan kepercayaan diri pada siswa. Dengan kata lain, pembelajaran adalah proses untuk membantu peserta didik agar dapat belajar dengan baik. Sedangkan proses pembelajaran merupakan suatu proses yang mengandung serangkaian pelaksanaan oleh guru dan siswa atas dasar hubungan timbal-balik yang berlangsung dalam situasi edukatif untuk mencapai tujuan tertentu. Interaksi atau hubungan timbal balik antara guru dan siswa ini merupakan syarat utama bagi berlangsungnya suatu proses pembelajaran. Pembelajaran suatu kegiatan yang dilakukan secara sadar dan sengaja.

Permainan (games) merupakan aktifitas umum yang dilakukan baik di lingkungan siswa, pemuda, maupun orang dewasa. Permainan merupakan kesibukan yang dipilih sendiri tanpa ada unsur paksaan dan tanpa didesak oleh rasa tanggung jawab. Permainan juga tidak memiliki tujuan tertentu. Permainan yang kita kenal saat ini, ternyata memiliki banyak ragam, ada yang bernama permainan fungsi yang bertujuan untuk melatih gerakan pada bayi, permainan konstruktif yang bertujuan pada hasil, permainan reseptif yang bertujuan kepada indra tubuh, permainan peranan yang bertujuan sebagai membangun karakter siswa dan permainan sukses yang bertujuan dalam bidang prestasi. Permainan akan berdampak negatif jika seseorang mengalami adiksi (kecanduan) sebagai contoh adiksi bermain game online.

Bermain game online memberikan dampak candu pada siswa sehingga mereka melupakan tugas mereka yang utama yaitu belajar. Akibatnya, dari segi akademik mereka akan mengalami penurunan prestasi belajar. Untuk dapat bermain game online mereka tentunya harus membayar menggunakan uang saku mereka. Jika dibiarkan tentu saja mereka akan menjadi siswa yang boros karena mereka pasti meminta tambahan uang saku dan akan terbiasa menggunakan uang untuk hal-hal yang tidak bermanfaat.

Berdasarkan hasil wawancara dengan guru BK, guru mata pelajaran dan siswa SMKN 2 Kendari disimpulkan bahwa ada kelas yang siswanya paling banyak bermain game online, yaitu kelas XI. Dari keterangan yang didapatkan dari guru mata pelajaran bahwa siswa yang diketahui sering bermain game online tidak melaksanakan tugas-tugas yang diberikan oleh gurunya. Adapun jika dikerjakan asal-asalan dan tidak sesuai dengan apa yang diarahkan, yang sering dilalaikan seperti pekerjaan rumah (PR) dan tugas mencatat. Saat proses belajarpun mereka kelihatan malas-malasan dan tidak bersemangat, ketika diberikan pertanyaan tentang pelajaran mereka seolah tidak ingin menjawabnya. Dari nilai tes yang diberikan guru terbukti banyak siswa yang bermain game online tidak mancapai nilai standar.

Berdasarkan hal tersebut, peneliti tertarik untuk melakukan penelitian di kelas XI untuk melihat perbedaan prestasi belajar siswa yang mengalami adiksi game online dan yang tidak mengalami adiksi game online. Tujuan penelitian ini untuk mengetahui perbedaan prestasi belajar siswa yang mengalami adiksi game online dengan siswa yang tidak mengalami adiksi game online di kelas XI SMKN 2 Kendari.

Belajar adalah perubahan tingkah laku sebagai akibat dari adanya interaksi antara adanya stimulus dan respon. Belajar dapat dilakukan dalam lingkungan keluarga, di dalam lingkungan 
bermain dan di dalam lingkungan belajar (lingkungan sekolah) (Surya, 2004). Dalam mengikuti proses pembelajaran di sekolah sudah pasti setiap siswa mengharapkan untuk dapat hak pengajaran yang baik dengan tujuan siswa memeroleh prestasi belajar yang baik. Oleh sebab itu dari pembelajaran yang baik akan menjadikan prestasi belajar yang memuaskan sehingga siswa dapat mencapai tujuannya.

Menurut Syah (2004) prestasi belajar adalah kemampuan-kemampuan yang dimiliki siswa setelah menerima pengalaman belajarnya. Prestasi belajar harus didasarkan pada pengamatan tingkah laku melalui stimulus respon (Sudjana, 2005: 19). Prestasi belajar berkenaan dengan kemampuan siswa di dalam memahami materi pelajaran. Menurut Slameto (2003) prestasi belajar adalah pola-pola perbuatan, nilai-nilai, pengertianpengertian, sikap-sikap, apresiasi, ablititas dan keterampilan.

Prestasi belajar tampak sebagai terjadi perubahan tingkah laku pada diri siswa yang dapat diamati dan diukur dalam bentuk perubahan pengetahuan, sikap dan keterampilan. Perubahan tersebut dapat diartikan terjadinya peningkatan dan pengembangan yang lebih baik dibandingkan dengan sebelumnya, misalnya dari tidak tahu menjadi tahu, sikap kurang sopan menjadi sopan dan sebagainya.

Menurut Slameto (2003) pembelajaran yang terjadi di sekolah diawasi oleh pihak sekolah, masyarakat dan pemerintah. Agar tujuan pembelajaran bisa tercapai perlu adanya kerjasama antara pihak-pihak tersebut. Dengan adanya perkembangan yang terjadi di setiap aspek kehidupan, maka perlu pengawasan yang lebih ketat kepada siswa. Pengertian prestasi belajar adalah kemampuan-kemampuan yang dimiliki siswa setelah menerima pengalaman belajarnya, (Syah, 2004).

Menurut Sukmadinata (2005), Pengukuran akan pencapaian prestasi belajar siswa dalam pendidikan formal telah ditetapkan dalam jangka waktu yang bersifat catur wulan dan sering disebut dengan istilah mid semester (UTS) dan ujian akhir semester (UAS), nilai ulangan harian, dan nilai tugas sehari-hari. tetapi dalam prestasi belajar diharapkan adalah peningkatan yang dilakukan dalam materi yang diajarkan. Untuk mengetahui prestasi belajar siswa perlu diadakan suatu evaluasi yang bertujuan untuk mengetahui sejauh manakah proses belajar dan pembelajaran itu berlangsung secara efektif. Banyak siswa yang melalaikan proses pembelajarannya demi melakukan hal yang disenanginya, seperti bermain game online. Oleh karena itu, perlu adanya saling kerjasama antara pihak sekolah untuk mencegah dan menangani masalah ini

Adiksi game online akan mengurangi aktivitas positif yang seharusnya dijalani oleh siswa pada usia perkembangan mereka. Siswa yang mengalami ketergantungan pada aktivitas game, akan mengurangi waktu belajar dan waktu untuk bersosialisasi dengan teman sebaya mereka. Jika ini berlangsung terus menerus dalam waktu lama, diperkirakan siswa akan menarik diri pada pergaulan sosial, tidak peka dengan lingkungan, dan meninggalkan aktivitas belajarnya. Menurut Freeman (2007) game online adalah game yang berbasis elektronik dan visual yang hampir semua permainannya sangat menimbulkan kecanduan, beberapa pemainnya dapat menghabiskan waktu berjam-jam, bahkan seharian penuh untuk memainkannya dan ada orang yang menghabiskan seluruh waktu jaganya untuk melakukan permainan ini, sehingga disebut sebagai adiksi game online. Adiksi game online ditandai oleh sejauh mana seseorang bermain game online secara berlebihan yang dapat berpengaruh negatif bagi pemain game tersebut. Kriteria adiksi game di antaranya adalah salience (pemain berpikir tentang bermain game sepanjang hari), tolerance (pemain menghabiskan waktu bermain game yang semakin meningkat), mood modification (pemain bermain game sampai melupakan kegiatan lainnya), relapse (kecenderungan pemain bermain game kembali setelah lama tidak bermain), withdrawal (pemain merasa tidak baik atau merasa buruk ketika tidak dapat bermain game), conflict (pemain bertengkar dengan orang lain karena pemain bermain game secara berlebihan), dan problems (pemain mengabaikan kegiatan penting lainnya yang akhirnya menyebabkan permasalahan) (Lemmens, 2009).

Termotivasi bermain game online akan menimbulkan efek adiktif, setiap orang memiliki dorongan dan alasan yang berbeda untuk bermain game online. Dorongan dan alasan yang berbedabeda akan menimbulkan motivasi bermain game online (Yee, 2006). Siswa yang termotivasi bermain game online akan terus memainkan game online yang akan berdampak kepada aktivitas otak remaja yaitu kerusakan otak di bagian prefrontal cortex (PFC) sehingga remaja akan menjadi kurang dapat berkonsentrasi dalam berbagai hal, 
menimbang benar atau salah, berkurangnya kemampuan mengambil keputusan (Sherry, 2013).

Faktor-faktor yang memengaruhi adiksi game online antara lain faktor atraksi dan motivasi, jenis kelamin, serta dukungan sosial. Faktor atraksi menyebabkan individu menjadi kecanduan karena adanya sesuatu yang menarik dari permainan (Yee, 2006), faktor motivasi merupakan kondisi di dunia nyata yang menekan sehingga mendorong untuk bermain games (Yee, 2006), jenis kelamin anak laki-laki lebih mudah menjadi adiksi terhadap games dan menghabiskan banyak waktu untuk bermain game, dan dukungan sosial yang merupakan faktor pelindung langsung dan tidak langsung bagi remaja bermain game online (Prabowo, 2012).

Faktor yang memengaruhi prestasi belajar menurut Sugihartono, dkk. (2007: 76- 77), adalah faktor yang terdapat dalam diri siswa, dan faktor yang ada di luar diri siswa. Faktor internal berasal dari dalam diri anak bersifat biologis, sedangkan faktor eksternal adalah faktor yang sifatnya dari luar diri siswa.

\section{Faktor Internal}

Faktor internal meliputi faktor fisiologis, yaitu kondisi jasmani dan keadaan fungsifungsi fisiologis. Faktor fisiologis sangat menunjang atau melatar belakangi aktivitas belajar. Keadaan jasmani yang sehat akan lain pengaruhnya dibanding jasmani yang keadaannya kurang sehat. Untuk menjaga agar keadaan jasmani tetap sehat, nutrisi harus cukup. Hal ini disebabkan, kekurangan kadar makanan akan mengakibatkan keadaan jasmani lemah yang mengakibatkan lekas mengantuk dan lelah.

Faktor psikologis, yaitu yang mendorong atau memotivasi belajar. Faktor-faktor tersebut diantaranya:

a. Adanya keinginan untuk tahu.

b. Agar mendapatkan simpati dari orang lain.

c. Untuk memerbaiki kegagalan.

d. Untuk mendapatkan rasa aman.

\section{Faktor Eksternal}

Faktor-faktor eksternal, yaitu faktor dari luar diri anak yang ikut memengaruhi belajar anak, yang antara lain berasal dari orang tua, sekolah, masyarakat, faktor teman bergaul dan aktifitas bermain.

a. Faktor yang berasal dari orang tua

Faktor yang berasal dari orang tua ini utamanya adalah sebagai cara mendidik orang tua terhadap anaknya. Dalam hal ini, dapat dikaitkan suatu teori, apakah orang tua mendidik secara demokratis, pseudo demokratis, otoriter atau cara laisses faire. Cara atau tipe mendidik yang demikian masing-masing mempunyai kebaikannya dan ada pula kekurangannya.

b. Faktor yang berasal dari sekolah

Faktor yang berasal dari sekolah, dapat berasal dari guru, mata pelajaran yang ditempuh dan metode yang diterapkan. Faktor guru banyak menjadi penyebab kegagalan belajar anak, yaitu yang menyangkut kepribadian guru, kemampuan mengajarnya. Terhadap mata pelajaran, karena kebanyakan anak memusatkan perhatianya kepada yang diminati saja, sehingga mengakibatkan nilai yang diperolehnya tidak sesuai dengan yang diharapkan. Keterampilan, kemampuan dan kemauan belajar anak tidak dapat dilepaskan dari pengaruh atau campur tangan orang lain. Oleh karena itu, menjadi tugas guru untuk membimbing anak dalam belajar.

c. Faktor teman pergaulan

Setiap anak pasti memiliki teman bergaul baik itu di sekolah maupun di luar sekolah. Dalam pergaulan ini anak saling memengaruhi antara satu sama lain, sehingga sangat memengaruhi aktifitas kesehariannya termasuk proses belajarnya. Jadi, dengan siapa dia bergaul akan memengaruhi prestasi belajar anak tersebut. Jika dia berteman dengan anak yang memiliki motivasi belajar tinggi maka anak tersebut juga akan tersuasana dan bisa meningkat motivasi belajarnya. Begitupun sebaliknya, jika mereka berteman dengan ank yang memiliki motivasi belajar rendah maka akan berdampak pada prestasi belajar anak tersebut.

d. Aktifitas bermain

Aktifitas bermain bagi anak adalah sesuatu yang wajar selama tidak mengganggu aktifitasnya yang lebih penting untuk masa perkembangannya. Banyak anak yang bermain sampai melupakan tugasnya yang utama yaitu belajar, sehingga hasil yang didapatkanpun tidak maksimal. Bentuk permainnanya beraneka ragam, tergantung dari suasana dan keadaan tempatnya tinggal. Bagi anak yang berada di daerah pedalaman dan terpencil, jenis permainan yang 
dilakukan masih sangat sederhana dan tradisional. Sedangkan bagi anak yang berada di daerah perkotaan permainan yang dilakukan sudah modern dan menggunakan teknologi bahkan ada yang menggunakan internet dalam penggunaanya. Banyaknya jenis permainan ini menambah keinginan bermain bagi anak lebih besar, waktu yang digunakanpun lebih banyak untuk bermain.

e. Faktor yang berasal dari masyarakat

Anak tidak lepas dari kehidupan masyarakat. Faktor masyarakat bahkan sangat kuat pengaruhnya terhadap pendidikan anak. Pengaruh masyarakat bahkan sulit dikendalikan. Mendukung atau tidak mendukung perkembangan anak, masyarakat juga ikut memengaruhi.

\section{Metode Penelitian}

Penelitian ini dilaksanakan di SMKN 2 Kendari selama 3 bulan pada tahun ajaran 2017/ 2018. Penelitian ini merupakan penelitian kuantitatif yaitu penelitian yang datanya berupa data dalam bentuk angka. Sedangkan menurut tingkat ekplanasi (penjelasannya) penelitian ini merupakan penelitian komparatif yaitu suatu penelitian yang bersifat membandingkan dua kelompok tertentu (Hamalik, 2007).

Subjek penelitian ini diambil dengan teknik purposive pada siswa kelas XI di SMKN 2 Kendari yang berjumlah 78 orang,. Kriteria inklusi pada penelitian ini adalah mengalami adiksi game online. Berhubung penelitian ini adalah penelitian komparatif maka jumlah kelompok pembanding menyesuaikan dengan jumlah kelompok yang mengalami adiksi game online. Masing-masing kelompok bejumlah minimal 30 siswa. Siswa dikelompokan berdasarkan skor angket yang telah diisi oleh siswa. Sedangkan jumlah siswa yang tidak mengalami adiksi game online akan disamakan dengan jumlah siswanya.

Adiksi game online pada penelitian ini diukur dengan Angket Adiksi Game Online (AAGO). Skor tertinggi AAGO adalah 280 dan skor terendahnya adalah 70. Siswa dikategorikan mengalami adiksi game online jika skor minimalnya 4/7 dari skor keseluruhan yaitu jika mencapai 160.

Teknik pengmpulan data pada penelitian ini ada 2 yaitu dokumentasi dan angket. Teknik dokumentasi pada penelitan ini adalah untuk mengukur prestasi belajar siswa melalui rerata nilai seluruh mata pelajaran pengetahuan. Nilai siswa akan diambil dari rapor siswa semester ganjil T.A. 2018/ 2019. Adapun kategori peniliaian dapat dilihat melalui interval rerata nilai siswa.

Tabel 1

Kategori rerata nilai siswa

\begin{tabular}{|c|c|}
\hline Interval Nilai & Kategori \\
\hline $75-85$ & Sangat Tinggi \\
\hline $64-74$ & Tinggi \\
\hline $53-63$ & Sedang \\
\hline $42-52$ & Rendah \\
\hline $31-41$ & Sangat Rendah \\
\hline
\end{tabular}

Sebelum angket digunakan maka akan dilakukan uji validitas butir dan reliabilitas angket. Untuk melakukan uji validitas butir dan reliabilitas angket digunakan program SPSS versi 17.0. Jumlah seluruh butir angket sebelum uji validitas dan reliabilitas 156 butir. Setelah uji validitas dan reliabilitas yang dilakukan pada 42 orang siswa, maka didapatkan 105 butir yang valid. Adapun yang dibutuhkan dalam penelitian ini berjumlah 70 butir dari seluruh indikator. Setiap indikator memuat 10 butir positif dan negatif yang ada didalam 105 butir yang valid.

Jumlah siswa ketiga kelas yang diteliti adalah 78 orang. yang mengisi Angket Adiksi Game online (AAGO) hanya 76 orang. Setelah mengisi AAGO maka siswa dibagi menjadi 2 kelompok berdasarkan hasil AAGO, kelompok siswa yang mengalami adiksi game online dan kelompok siswa yang tidak mengalami adiksi game online. Total skor AAGO adalah 280 yang terdiri dari 70 item pernyataan. Menurut teori Lemmens (2009), siswa dikategorikan mengalami adiksi game online jika total skornya lebih dari 4/7 total skor keseluruhan. Jumlah skor minimal adalah 160, jika tidak mencapai 160 maka di kategorikan tidak mengalami adiksi game online. Dari 76 siswa yang mengisi AAGO ada 33 siswa yang skornya diatas 160, sedangkan 43 siswa lainnya skornya dibawah 160 .

Jumlah siswa yang tidak mengalami adiksi game online disesuaikan dengan jumlah siswa yang mengalami adiksi game online yaitu 33 siswa. Kedua kelompok tersebut akan dihitung uji beda (independent t-test) menggunakan SPSS versi 17.00. Pengolahan dan analisis data dalam penelitian ini dilakukan terhadap nilai hasil ujian akhir semester siswa dan hasil Angket Adiksi Game Online (AAGO). Setelah mengelompokan siswa yang mengalami adiksi game online dan 
yang tidak mengalami adiksi game online, maka akan dihitung rerata nilai rapor siswa yang ada pada kedua kelompok tersebut. Pada penelitian ini menggunakan program SPSS versi 17.0.

\section{Hasil Penelitian dan Pembahasan}

\section{Hasil Penelitian}

Analisis Deskriptif

Di bawah ini tabel rerata nilai rapor siswa MAGO (Mengalami Adiksi Game Online) dan TMAGO (Tidak Mengalami Adiksi Game Online).

Tabel 2

Rerata Nilai Rapor Siswa

\begin{tabular}{|c|c|c|c|}
\hline Resp & MAGO & Res. & TMAGO \\
\hline 1 & 71 & 1 & 61 \\
\hline 2 & 51 & 2 & 62 \\
\hline 3 & 64 & 3 & 66 \\
\hline 4 & 63 & 4 & 63 \\
\hline 5 & 68 & 5 & 67 \\
\hline 6 & 62 & 6 & 65 \\
\hline 7 & 54 & 7 & 77 \\
\hline 8 & 44 & 8 & 63 \\
\hline 9 & 61 & 9 & 72 \\
\hline 10 & 60 & 10 & 56 \\
\hline 11 & 62 & 11 & 75 \\
\hline 12 & 66 & 12 & 70 \\
\hline 13 & 60 & 13 & 74 \\
\hline 14 & 52 & 14 & 73 \\
\hline 15 & 50 & 15 & 79 \\
\hline 16 & 31 & 16 & 71 \\
\hline 17 & 70 & 17 & 79 \\
\hline 18 & 50 & 18 & 82 \\
\hline 19 & 75 & 19 & 81 \\
\hline 20 & 72 & 20 & 77 \\
\hline 21 & 69 & 21 & 78 \\
\hline 22 & 72 & 22 & 75 \\
\hline 23 & 72 & 23 & 74 \\
\hline 24 & 66 & 24 & 77 \\
\hline 25 & 52 & 25 & 66 \\
\hline 26 & 67 & 26 & 73 \\
\hline 27 & 58 & 27 & 80 \\
\hline 28 & 78 & 28 & 60 \\
\hline 29 & 59 & 29 & 64 \\
\hline 30 & 45 & 30 & 81 \\
\hline 31 & 72 & 31 & 82 \\
\hline 32 & 71 & 32 & 78 \\
\hline 33 & 74 & 33 & 61 \\
\hline Rerata & 61,84 & Rerata & 71,57 \\
\hline
\end{tabular}

Selanjutnya, data mengenai rerata skor AAGO antara siswa yang MAGO dan siswa yang TMAGO dapat dilihat melalui table berikut ini:
Tabel 4

Rerata Skor AAGO siswa

\begin{tabular}{|c|c|c|c|}
\hline Resp & MAGO & Resp & TMAGO \\
\hline 1 & 170 & 1 & 110 \\
\hline 2 & 173 & 2 & 115 \\
\hline 3 & 168 & 3 & 108 \\
\hline 4 & 174 & 4 & 111 \\
\hline 5 & 165 & 5 & 126 \\
\hline 6 & 201 & 6 & 113 \\
\hline 7 & 174 & 7 & 117 \\
\hline 8 & 178 & 8 & 122 \\
\hline 9 & 190 & 9 & 123 \\
\hline 10 & 177 & 10 & 102 \\
\hline 11 & 173 & 11 & 117 \\
\hline 12 & 182 & 12 & 108 \\
\hline 13 & 176 & 13 & 127 \\
\hline 14 & 173 & 14 & 109 \\
\hline 15 & 170 & 15 & 120 \\
\hline 16 & 174 & 16 & 127 \\
\hline 17 & 173 & 17 & 116 \\
\hline 18 & 174 & 18 & 107 \\
\hline 19 & 163 & 19 & 113 \\
\hline 20 & 182 & 20 & 114 \\
\hline 21 & 176 & 21 & 111 \\
\hline 22 & 163 & 22 & 128 \\
\hline 23 & 169 & 23 & 107 \\
\hline 24 & 170 & 24 & 122 \\
\hline 25 & 172 & 25 & 120 \\
\hline 26 & 165 & 26 & 118 \\
\hline 27 & 187 & 27 & 117 \\
\hline 28 & 253 & 28 & 118 \\
\hline 29 & 175 & 29 & 124 \\
\hline 30 & 261 & 30 & 101 \\
\hline 31 & 180 & 31 & 130 \\
\hline 32 & 170 & 32 & 115 \\
\hline 33 & 170 & 33 & 106 \\
\hline Rerat & 179,4 & Rera & 115.8 \\
\hline
\end{tabular}

Masing-masing siswa yang mengalami adiksi game online memiliki kadar adiksi yang berdeda-beda tergantung skor AAGO. Selain itu, rerata nilai siswa juga berbeda. Kadar adiksi dan rerata nilainya disajikan melalui data interval dengan pedoman berikut ini:

$\mathrm{I}=$ Interval

$\mathrm{S}_{\mathrm{t}}=$ Skor tertinggi

$\mathrm{S}_{\mathrm{r}}=$ Skor terendah

$\mathrm{K}=$ Klasifikasi

$\mathrm{I}=\frac{S_{t-S_{r}}}{k}=$ Interval $=\frac{280-160}{3}=40$ 
Tabel 4

Kadar Adiksi dan Rerata Nilai Siswa MAGO

\begin{tabular}{|c|c|c|c|}
\hline No & $\begin{array}{c}\text { Kategori } \\
\text { Adiksi }\end{array}$ & Skor & Rerata \\
\hline 1 & Tinggi & $242-280$ & 62.5 \\
\hline 2 & Sedang & $201-241$ & 67 \\
\hline 3 & Rendah & $160-200$ & 61.6 \\
\hline
\end{tabular}

Dari tabel di atas diketahui bahwa kadar adiksi sebagian besar siswa yang mengalami adiksi game online adalah rendah.

Analisis statistik inferensial

Hasil uji beda (uji t) menunjukkan nilai Sig. 2 tailed 0,00 . Nilainya $<0,05$ yang berarti $\mathrm{H}_{0}$ ditolak, artinya terdapat perbedaan yang signifikan prestasi siswa yang mengalami adiksi game online dan yang tidak mengalami adiksi game online. Nilai siswa yang tidak mengalami adiksi game online lebih tinggi dari nilai siswa yang mengalami adiksi game online.

Tabel 6

t-Test for Equality of Means

\begin{tabular}{|l|r|r|r|}
\hline & Df & $\begin{array}{r}\text { Sig. (2- } \\
\text { tailed) }\end{array}$ & $\begin{array}{r}\text { Mean } \\
\text { Difference }\end{array}$ \\
\hline $\begin{array}{l}\text { Equal variances } \\
\text { assumed }\end{array}$ & 64 & .000 & -11.48485 \\
\hline
\end{tabular}

\section{Pembahasan}

Menurut Lemmens (2009) adiksi game online ditandai oleh seseorang bermain game online secara berlebihan yang berpengaruh negatif bagi aktifitas-aktifitas lain yang dilakukan pemain game tersebut, sedangkan menurut Young (2009) adiksi game online ditandai dengan pemain bermain game online secara berlebihan seakanakan tidak ada hal yang ingin dikerjakan selain bermain game dan seolah-olah game online ini adalah hidupnya.

Siswa yang mengalami adiksi game online hanya fokus pada permainannya, sehingga acuh pada aktifitas yang ada di sekitarnya termasuk yang berhubungan dengan pelajarannya. Nilai siswa menurun karena siswa tidak memerhatikan pelajarannya baik saat berada di sekolah maupun di rumah misalnya malas ke sekolah, tidak kerja tugas, malas belajar, nasehat-nasehat orang tua dan guru diabaikan.

Siswa yang mengalami adiksi game online kurang berkonsentrasi pada aktifitas lain, bayang- bayang game online akan terus muncul dipikirannya, sehingga pikirannya terfokus pada permainannya saja. Siswa tidak bisa konsentrasi saat guru menjelaskan di sekolah, jika diberikan soal tidak bisa dijawab, banyak melamun, tidak bisa membedakan mana yang salah dan yang benar dan ragu-ragu dalam bertindak. Sesuai dengan teori yang dikemukakan Sherry (2013) bahwa siswa yang mengalami adiksi game online akan terus memainkan game online yang akan berdampak kepada aktivitas otak remaja yaitu kerusakan otak di bagian prefrontal cortex (PFC) sehingga remaja akan menjadi kurang dapat berkonsentrasi dalam berbagai hal, menimbang benar atau salah serta berkurangnya kemampuan mengambil keputusan.

Siswa yang mengalami adiksi game online menggunakan sebagian besarnya waktunya untuk bermain game online sehingga waktunya untuk pelajaran tidak ada. Seluruh kesibukan lain diabaikan demi bermain game online. Tugas-tugas yang diberikan di sekolah tidak sempat dikerjakan, tidak sempat belajar di rumah, sehingga berdampak pada prestasi belajarnya yang rendah. Menurut Freeman, (2007) pemain game online dapat menghabiskan waktu berjam-jam, bahkan seharian penuh untuk memainkannya dan ada orang yang menghabiskan seluruh waktu jaganya untuk melakukan permainan ini.

Penelitian ini juga mendukung penelitian sebelumnya yang dilakukan Khairani dan Beydha (2013) yang menunjukkan prestasi belajar siswa yang mengalami adiksi game online terjadi penurunan dibandingkan sebelum mengalami adiksi game online.

Setiap penelitian memiliki keterbatasan dari sisi yang berbeda. Keterbatasan penelitian ini adalah pengambilan sampel pada penelitian ini hanya berdasarkan angket saja, sehingga peneliti mengategorikan siswa mengalami adiksi atau tidak adiksi sepenuhnya hanya menggunakan data dari angket yang diisi siswa tanpa menggunakan instrumen lain. Aktifitas bermain game online siswa tidak pernah teramati secara langsung oleh peneliti, sehingga bisa saja mereka bukan yang mengalami adiksi game online atau sebaliknya.

\section{Kesimpulan}

Dari hasil penelitian dapat disimpulkan bahwa terdapat perbedaan yang signifikan prestasi belajar antara siswa yang mengalami adiksi game online dan siswa yang tidak mengalami adiksi game online. 


\section{Saran}

1. Bagi sekolah. Untuk mengurangi kacanduan yang dialami siswa, sebaiknya pihak sekolah membuat aturan yang lebih tegas dan menindak siswa-siswa yang membawa Handphone di sekolah.

2. Bagi guru BK, sebaiknya memberikan layanan informasi untuk mencegah siswa yang belum mengalami adiksi game online dan layanan yang bisa mengurangi kecanduan pada siswa yang sudah telanjur mengalami adiksi game online.

3. Bagi siswa, diharapkan mampu menjauhi bermain game online secara berlebihan baik di sekolah maupun di luar sekolah.

\section{Daftar Pustaka}

Freeman, C. B. (2007). Internet gaming addiction . The Journal for Nurse Practitioner - JNP. American College.

Hamalik, Oemar. (2007). Metodologi Penelitian Kualitatif. Surakarta: UNS Press.

Lemmens, J. S., Valkenburg, P. M. dan Peter, J. (2009). Development and validation.

Lemmens, J. S., Valkenburg, P. M., \& Gentile, D. A. (2015). The Internet Gaming Disorder Scale. Psychological Assessment. Advance Online publication.

Mohamad Surya. (2004). Psikologi Pembelajaran dan Pengajaran. Bandung: Pustaka Bani Quraisy.

Muhibbin Syah. (2004). Psikologi Pendidikan Dengan Pendekatan Baru. Jakarta: Rajawali.

Prabowo, O. (2012). Hubungan Antara Penerimaan Teman Sebaya dan Kesepian dengan Kecanduan Gim Daring (Online Game) pada Remaja di Jakarta. Jurnal. Binus University.

Slameto. (2003). Belajardan Faktor-faktor yang memengaruhinya. Jakarta: PT Rineka Cipta.

Sudjana, N. (2005) Penilaian Hasil Proses Belajar Mengajar. Bandung: PT. Remaja Rosdakarya.
Sugiyono. (2010). Metode Penelitian Kuantitatif Kualitatif dan $R \& D$. Bandung: CV. Alfabeta.

Yee. (2006). Facets: 52 Motivation Factors for Why People Play MMORPG's http://www.nickyee.com/facets/home.html.

Young, K. (2009). Understanding online gaming addiction and treatment issues for adolescents.The American Journal of Family Therapy, 37, 355-372. 